ARTICLE

Received 15 Jun 2015 | Accepted 7 Sep 2015 | Published 13 Oct 2015

DOI: $10.1057 /$ palcomms.2015.31

OPEN

\title{
Hermeneutics and genocide: giving voice to the unspoken
}

\author{
Shawn Kelley ${ }^{1}$
}

\begin{abstract}
The discipline of philosophical hermeneutics, which has played a crucial role in the discipline of New Testament studies, is haunted by the Holocaust. While there has been a great deal of Heidegger scholarship on the interface of Heidegger's Nazi engagement and his thought, such scholarly focus has been lacking in the larger field of hermeneutics. Current hermeneutical theorists have not explored the various ways that hermeneutical theorists may be responding to the Holocaust. This paper seeks to rectify this scholarly lacuna by drawing attention to what is largely unspoken in hermeneutical theory. My argument examines one particularly important strain of hermeneutical thinking should be seen as a response to fascism and genocide: the critique of instrumental rationality. I look at three seminal sets of scholars: Heidegger, Gadamer and the Frankfurt School. The three sets of thinkers share remarkably similar views about the ills of modernity and a remarkably similar philosophical narrative on how these ills came about. In this grand narrative, current political or social problems are surface symptoms of a deeper spiritual crisis produced by the Enlightenment. The bulk of the paper consists of a reading of central elements of the thought of Heidegger, Gadamer and the Frankfurt School. This reading demonstrates that, for each, the critique of instrumental rationality represents their fundamental approach to confronting fascism and genocide. In the course of the analysis, I identify the limitations of this approach as both a ground for an ontological approach to interpretation and a theoretical response to the problems of fascism and genocide. If hermeneutics wishes to confront the Holocaust, then it needs to allow the Holocaust to become the explicit rather than implicit horizon and, thereby, to allow the emergence of a new set of questions that will produce a new turn in the hermeneutical dialogue. This paper is published as part of a thematic collection dedicated to radical theologies.
\end{abstract}

\footnotetext{
${ }^{1}$ Religion and Philosophy, Daemen College, Williamsville, NY, USA (email: SKelley@daemen.edu)
} 


\section{Introduction}

or most of the twentieth century, the philosophical discipline of hermeneutics provided biblical scholarship with its fundamental theoretical and interpretive foundation. To read the Bible seriously, especially the New Testament, was to engage with hermeneutics. The purpose of this paper is to read hermeneutical theory, which has played a crucial part in New Testament scholarship, as a post-Holocaust and postGenocidal discourse. My claim is that fascism and genocide were important topics for the formation of hermeneutics, and that hermeneutics has debated the fundamental nature of fascism and genocide by way of its critique of Enlightenment and technical rationality. My claim is a strong one: the hermeneutical debate about instrumental rationality and the Enlightenment is, among other things, explicitly about fascism and genocide and was intended to be so by the major figures in the field. As hermeneutical theory was translated into the field of New Testament studies, its overt political orientation fell by the wayside. New Testament scholarship would be wise to revisit the foundations of hermeneutical theory.

I will begin by offering a brief overview of current scholarly approaches to hermeneutics. Within New Testament scholarship, current research focuses on the traditional philosophical questions of meaning and the nature of interpretation. Within philosophy, however, there exists an increasing body of work dedicated to untangling the relationship between Nazism and Heidegger, the seminal figure who founded modern hermeneutics. This overview provides a foundation for exploring the way that hermeneutical theory addresses both fundamental philosophical and political-social questions.

With this analysis completed, I will begin to make the case that hermeneutics is fundamentally concerned with the nature of fascism and genocide. I will look closely at the pervasive hermeneutical debates about the Enlightenment and enlightened and technical rationality. I will argue that these debates, for those engaging them, were explicitly and self-consciously social and political in nature. For figures like Heidegger, the Frankfurt School and Gadamer, the critique of Enlightenment rationality was always both philosophical and political-social. The critique of Enlightenment rationality was a way of addressing political-social questions philosophically. Central to hermeneutics was the claim that fundamental philosophical critique was necessary to make sense of the most pressing issues of the day. As Gadamer argued, hermeneutics represents "a thoughtful mediation with contemporary life" (Gadamer, 1988: 150). In the years between 1933 and the mid-1950s, there was no more pressing issue than the prospects, nature and consequences of genocide and fascism.

\section{Current scholarship}

The questions I seek to pose to hermeneutical theory tend to be unasked by hermeneutical scholars, especially within the discipline of biblical scholarship. Hermeneutical theory takes up the question of interpretation or more specifically the structural conditions that make interpretation possible. Pushed by feminism, scholars of colour and postcolonialists, literary critical scholarship has been much more attentive to the way that ideological issues can become woven into abstract positions. This critical attention has not yet migrated back to the discipline of hermeneutics.

Let us take as examples two recent, laudable works of hermeneutical theory within the discipline of New Testament studies, Porter and Stovel and Porter and Robinson. The first volume summarizes the major hermeneutical approaches to meaning (Porter and Stovel, 2012: 9-23) while the second introduces a wide range of hermeneutical thinkers and schools of thought (Porter and Robinson, 2011). In both instances, the emphasis on meaning is in keeping with hermeneutics as it was defined in the traditional understanding of the seminal texts of Heidegger, Gadamer and Ricoeur. While there is engagement with postmodernism and Derridean deconstruction (see Porter and Robinson, 2011, Chapter 8), the postmodernist view is presented as providing an especially radical answer to the specific, hermeneutical question of the foundation of interpretation and meaning rather than as offering a fundamental critique of the seminal texts. While positing a particularly radical answer, this analysis still assumes the centrality of the traditional question of meaning. Neither volume addresses, in a systematic manner, the connection between fascism and hermeneutics.

In both instances, the emphasis on meaning is in keeping with hermeneutics as it was defined in the seminal texts of Heidegger, Gadamer and Ricoeur. While there is engagement with postmodernism and Derridean deconstruction (see Porter and Robinson, 2011, Chapter 8), the postmodernist view is presented as providing an especially radical answer to the specific, hermeneutical question of the foundation of interpretation and meaning. Current analysis continues to see the question of meaning - whether stable, inaccessible or somewhere in between - as the defining question of hermeneutics. Neither volume addresses, in a systematic manner, the connection between fascism and hermeneutics.

Porter and Robinson do not shy away from the way that various thinkers were entangled with the Nazi regime (see 50, 59, 76, 107, 133-134), and point to a recent biography of Gadamer, which covers the Nazi era in great detail. Unfortunately, there is little attempt to integrate these biographical facts into the analysis and, in the end, they are no more relevant than other biographical data such as year of birth or undergraduate institution. Engagement with Nazism is, for Porter and Robinson, an interesting biographical fact that has little significance for the thought of various hermeneutical scholars. Their reading of Gadamer's Truth and Method is rich, philosophically informed and engaging on a variety of levels, but one does not entertain the possibility that it could be a response to Nazism. My reading of Gadamer will be quite different in this respect.

These omissions are most revealing in Porter and Robinson's reading of Heidegger, which strikes me as the weakest part of their otherwise outstanding volume. Their analysis of Heidegger's Nazism is disappointingly tentative and tepid. "(Heidegger's) specific political beliefs have been debated by scholars, but his involvement with Nazism is undisputed ... Yet despite his political involvements, Heidegger continues to find vast audiences around the world" (59). There exist three recent and extremely widely read biographies that grapple with Heidegger's Nazism (Ott, Farias, Safranksi) and these biographies, whatever their differences, reveal that Heidegger's Nazism is one of modern philosophy's most difficult and pressing problems. It is, frankly, shocking that Porter and Robinson discuss the Grondin biography of Gadamer and never even allude to any of the biographies of Heidegger. The debates about Heidegger's Nazism have been heated enough to spill over into the popular press (see Kelley, n. 6, pp 228-229) and have played a crucial role in two decades of Heidegger scholarship. The omission of this debate is both unfortunate and revealing about the unwillingness of New Testament-inspired hermeneutics to engage the question of the interface of hermeneutics and fascism/genocide.

Even more pressing is the omission of any discussion of the growing body of philosophical critiques of Heideggerian fascist thought. If there have been multiple biographies of Heidegger's life there has been a two-decade-long explosion of scholarship on Nazism in Heidegger's thought, none of which makes its way into their analysis. While they do mention that many theologians have avoided him because of his atheism and involvement with National Socialism (71), they do not name names or discuss how his thought 
may (or may not) be infected by his political engagement. They are far more critical of his philosophical incoherence (70) than they are of his fascism. At the very least it would have been helpful to point the reader towards some of the philosophically grounded critiques of Heideggerian fascism. With that in mind, I shall highlight some of the recent twists and turns in this ongoing debate.

Throughout the mid-1980s it was possible to see Heidegger as a philosopher primarily concerned with the question of meaning and of being who also made some short-term but quite foolish political choices. That position fell apart with the biographical research of Farias and especially Ott, who demonstrated that Heidegger's commitment was deeply felt and spilled over to his thought. After the initial furor, a large number of philosophers offered careful, thoughtful, detailed readings of Heidegger's texts. These diverse scholars re-read Heidegger's thought in light of his political commitments and the ever-increasing number of available texts, lectures, speeches and seminars. Especially in American scholarship, a whole new picture of Heidegger began to emerge (for my analysis, see Kelley, 2002: 89-95). This debate continues without resolution, as can be seen in the three recent scholarly works of Emmanuel Faye, James Phillips and Charles Bambach. These three works, which were published after my last foray into the issue, show that the debate continues to rage within philosophy.

These three volumes echo debates that have raged around Heidegger since the end of the war. Emmanuel Faye offers the most recent version of Adorno's argument that Heidegger's thought is fascist down to its innermost core. He identifies philosophical support for the following Nazi ideas: eugenics (6869, 179), the Führer cult $(77-78,105,121,133,139-140)$, military conquest $(81-82,143-144,270-271)$, the superiority of völkisch thought over humanistic thought (90-92), explicit racism (100, $102,110,158,169-170,273-282,284-289,300-301)$, the Nazi, racist state $(115-119,125,208-215,221-224)$, the SS (123), persecution of the enemy $(129,152-154)$, the need to align the law to Nazi principles (154-158, 173-202, 205-208), and racial selection and genocide (244-246, 258-262, 271-272). For Faye, Heidegger's thought is so compromised that his philosophy is reducible to Nazism. James Phillips, on the other hand, follows the long-held position that emphasizes the disjunction between Heidegger and fascism. Phillips sees a "convergence" but "not an identity" between the Heideggerian and Nazi views (Phillips, 2005: 130). Phillips asks us to recognize that Heidegger's embrace of Nazi terminology and views included, alongside proximity, the seeds of a rupture with Nazism. If Faye collapses Heidegger into Nazism, and Phillips emphasizes the distance between Heidegger's private National Socialism and the policies of the Hitler regime, Charles Bambach asks not whether he was a Nazi but instead what sort of National Socialist he was (Bambach, 2003: xviii). Answering this question requires carefully reconstructing a range of thinkers on the radical right and then locating Heidegger's thought within this larger debate. For Bambach, Heidegger is both working within the orbit of the Nazified radical right and struggling to articulate his own position, often in opposition to other elements of the radical right (for an initial summary of his claims, see xxiv-xxv).

Before concluding this section on current scholarship, it is worth mentioning one more aspect of the inexhaustible Heidegger affair. Beginning in 1931, Heidegger kept "Black Notebooks" reflecting his nascent and underdeveloped ideas. These notebooks, which will soon be published, are rumored to contain further evidence of Heidegger's political views and anti-Semitism. Peter Trawney, the volume's editor, has come to argue that Heidegger was far more anti-Semitic than had been realized and believed deeply in the existence of an international Jewish conspiracy dedicated to the destruction of the West. Clearly this debate has yet to run its course.
A large number of very thoughtful and careful philosophical arguments have been offered that try to re-read Heidegger's thought in light of his political commitments and the everincreasing number of available texts, lectures, speeches and seminars given during the Nazi era. Despite their differences, all three approaches show that philosophers are examining Heidegger's thought for its engagement with fascism and genocide. A similar confrontation should take place with the discipline that Heidegger helped to create: Hermeneutics.

\section{The Holocaust and the critique of Enlightenment rationality} In this section I will look at three foundational hermeneutical figures whose lives and thought were profoundly shaped, in very different ways, by the Nazi era. All three made very different political choices but all shaped their responses to this disruptive era in the same way: through the critique of instrumental rationality. There was hardly agreement on the political analysis, with Heidegger embracing fascism, the Frankfurt School embracing socialism and Gadamer decrying the politicization of the Western tradition. I do wish to show, however, that there is surprising similarity in the structure of analysis. In each instance, the central assumption was that the political crisis of the Weimar and Nazi eras reflected and grew out of a profound philosophical/hermeneutical crisis. The political situation, grave as it was, was but a symptom of a deeper philosophical-spiritual cause. It was philosophy's urgent task to address that deeper spiritual crisis and, by doing so, the philosophers were explicitly and self-consciously addressing the political crisis of the day.

In addition to sharing this fundamental belief that the political crisis grows out of, and reflects, deeper spiritual-philosophical currents, all the thinkers being analysed share a remarkably similar structure of analysis. They all assume a historical narrative with several crucial time markers - a time of purity, a fateful misstep setting in motion inevitable decline. The moment of purity and the initial missteps both occurred in the realm of the ancient Greeks, while the decline was greatly accelerated by the Enlightenment. Drawing on longstanding anti-Enlightenment sentiment, all three thinkers criticized the Enlightenment for elevating scientific, instrumental reason above all else, grounding knowledge in the autonomous human subject, and opening the doors to atomism, rootlessness, alienation and reification. With these fateful missteps, modernity took a wrong turn that culminated in the crisis of Weimar, fascism and genocide. They address genocide by analysing and critiquing Enlightenment rationality and by tracing the error back to its origins.

I shall very briefly summarize the position of each thinker before providing supporting and textual evidence. Heidegger's embrace of Nazism will revolve around his critique of Enlightenment, instrumental rationality (which he sees as the cause of the current intellectual and political crisis), which he sees as growing out of flaws inherent in Western metaphysics going back to the Greeks. For Gadamer, the most pressing problem is to rehabilitate the great Western tradition from the taint of fascism and genocide. This rehabilitation project was grounded in Gadamer's critique of Enlightenment, instrumental rationality, which he sees a growing out of flaws inherent in Western metaphysics. In the course of their analysis, Horkheimer and Adorno offered a philosophical critique of the ground fascism, which they trace to flaws in Enlightenment, instrumental rationality, which is itself a product of tensions and flaws in Western thought going back to the Greeks. I hope that this analysis will encourage my reader to ask whether the critique of instrumental reason is adequate to the task of confronting the essence of fascism and genocide. 


\section{Heidegger}

There has never been any doubt that Martin Heidegger, founder of modern hermeneutics, was a member of the Nazi party and a vocal and public supporter of Hitler. The question has been what to make of these actions. The recent research of Ott, Farias and Safranski reveals the depth of Heidegger's commitment in painstaking, careful detail. These actions include instituting Nazi educational and racial policies (Ott, 1993: 169; Farias, 1989: 119; Faye, 2009: 43-46; Heidegger, 1993a: 34), sending fawning telegrams to high-ranking Nazis (Ott, 1993: 169-175) and giving a number of high-profile political speeches (see Wolin, 1993: 4066). These speeches employ explicitly Nazi language and imagery (that is, Volk, race, destiny, Führer, racial community, hardness, discipline, struggle) that enthusiastically endorsed Nazi policies as they heaped praise upon Nazi martyrs, the regime, student radicals and Hitler himself. While he did not engage in the sort of public anti-Semitism that was so dominant at the time, there is a significant amount of evidence of anti-Semitic sentiment on his part (see Lang, 1996: 36-38, 70-72; Grondin, 2003: 69-70; Safranski, 1998: 257).

Heidegger sought to gain control of the university and use it as a base for seizing control of the National Socialist reorganization of the university system (Safranski, 1998: 235-238). Given his view that political reality reflected deeper metaphysical foundations, his ambition is simply breathtaking. By taking control of his university, and using it as a base to reform all the German universities, his goal was nothing less than to ground the National Socialist revolution in his hermeneutical phenomenology and thereby take control of the revolution. His ambition was to turn the Nazi era into a hermeneutical one.

As Heidegger's thought wove its way down and through various pathways, his position on the Enlightenment and Enlightenment rationality remained consistent. He was against them both. This opposition worked itself out in a variety of complex and oft-changing ways, but it was invariably connected to both crucial aspects of his thought and to his (again, oftchanging) political analysis. The Enlightenment becomes, for him, an all-purpose explanation - it explains why democracy fails, why the Nazi revolution was necessary, why the revolution failed and why the authentic but failed revolution committed genocide. I will draw attention, in an overly brief manner, to two moments where Heidegger's critique was related explicitly to the question of fascism or, later, genocide.

Heidegger's revolution and Enlightenment rationality. Heidegger's early thought attempts to reconfigure the relationship between self and world, a relationship that Heidegger is convinced has been badly misunderstood since the inception of Western philosophy (for my analysis, see Kelley, 96-100). The problem stems from the human desire to flee from the flux of human existence and seek refuge in an illusory permanence. For Heidegger the vast majority of Western philosophy has taken the wrong path and has obscured, rather than clarified, the structure of existence (see Kisiel, 1995: 156, van Buren, 1994: 141). Western Philosophy has set us on the wrong path and the result is mistaken categories that produce further confusion and errors, most especially the twin errors of the autonomous subject and the elevation of science as a mode of reasoning, producing instrumental reason, objectification and reification. The attempt to identify and solve this problem forms the backbone of what the early Heidegger defines as the hermeneutics of facticity as found in his unpublished but reconstructed early lectures and in Being and Time. Hermeneutical philosophy requires a double move: the destruction of the flawed tradition and, once the chaff has been cleared away, the proper reconstruction of the ontological conditions of human existence in the world.
Initially, then, hermeneutics was not about interpretation at all but was deeply tied to Heidegger's developing phenomenology of human existence. It was, for Heidegger, a way of doing philosophy without falling prey to the temptation of reification and objectification that emerged out of a failed philosophical tradition. The flaws, for Heidegger, started in the ancient world and have only snowballed over the years. The key turning point, which is behind the current crisis, is the Enlightenment with its enshrinement of the autonomous subject, its elevation of technological reason, and its embrace of the Natural Sciences and the value and method of objectivity and of objectification. The roots of the problem reside deep in the origins of Western Philosophy, but it is with the Enlightenment that thought took a fateful turn and established the conditions for the doomed world of modernity. Philosophy can only gain its footing if it is able to get behind and then beyond the instrumental reasoning that emerged out of the Enlightenment. Society may be in a state of chaos and decay (and it is worth recalling that Heidegger is writing during the chaotic Weimar years), but this chaos and decay is but a symptom of a deeper problem. Without addressing the fundamental, ontological problem, modernity will continue to bounce from horrible crisis to horrible crisis. What is required is a philosophical revolution.

When the Nazi revolution explodes upon the scene, Heidegger seizes the moment. For Heidegger, this configuration of events cannot be coincidental - the revolution on the political level must reflect the profound spiritual revolution that he has been initiating at the philosophical level. While others are fighting over mundane matters like book burnings and forced sterilization, Heidegger works to steer the revolution towards something more primordial, fundamental and philosophical. He makes his case in his inaugural address The Self-Assertion of the German University. Authentic questioning, grounded in his thinking, would replace the degraded, enlightened so-called thinking that dominates modernity. He describes the West as a failing "moribund, pseudocivilization". The "spiritual strength of the West" now "fails", "starts to come apart at the seams" and "collapses into itself" (Heidegger, 1993a: 38). This new thinking will shatter the enlightened, scientific, discipline-based university and create a new, spiritual people. "Questioning will then unfold its ownmost power for disclosing the essence of all things ... Such questioning will shatter the encapsulation of the various fields of knowledge into separate disciplines ... If we will the essence of science in the sense of the questioning, unsheltered standing firm in the midst of the uncertainty of the totality of being, then this will to essence will create for our Volk ... a truly spiritual world" (Heidegger, 1993a: 33, see also 37).

The crisis stems from a misreading that happened all the way back in ancient Greece and the solution requires a return to the Greeks. If in his early thought Heidegger located the error in Plato and the solution in a certain reading of Aristotle, now he pushes the original error back even further. The great beginning of Western metaphysics occurred with the Greeks. "Only when we submit to the power of the beginning of our spiritual historical existence. This beginning is the beginning of Greek philosophy. That is when, from the culture of one Volk and by the power of that Volk's language, Western man rises up for the first time ... and questions" (Heidegger, 1993a: 31). This great Greek beginning was misunderstood almost as soon as it occurred, and it has seen nothing but decline ever since, with the Enlightenment setting the philosophical errors in cement. His Nazi revolution means repeating that great beginning, on a more authentic level of originary questioning, and courageously continuing this questioning. Unlike Plato and Aristotle, who turned away from the originary moment, the German revolution would, under Heidegger's leadership, continue in the pure quest. 
With this radical questioning, a rootless people would finally become rooted in their historical destiny. "Thus exposed to the extreme questionableness of its own existence, this Volk has the will to be a spiritual Volk" (Heidegger, 1993a: 35). If the university needed to be reorganized, this entailed removing the husk of a dead and decadent liberal humanism and its ultimate tool, Enlightenment-inspired instrumental reason. Once he made this commitment to join the revolution to better shape it, all of the terrible political decisions and compromises inevitably followed. The concentration camps, sterilization, anti-Semitic laws and book burnings were a small price to pay for the chance to restart Western philosophy anew.

Enlightenment reason and genocide. One of Heidegger's central post war topics involved technology as a reflection of flawed, Enlightenment-inspired modes of thinking. He had hoped that the Nazi revolution would lead to a head-long confrontation and resolution of this problem, but later came to see the Nazis as part of the problem rather than the solution. He alludes to this in the posthumously published interview in which he discusses the need to develop an adequate relation to the essence of technology and says, "National Socialism, to be sure, moved in this direction. But those people were far too limited in their thinking to acquire an explicit relationship to what is really happening today and has been underway for three centuries" (Heidegger, 1993b: 111). When he does discuss Nazism he sees it as either a failed confrontation with Enlightenment-produced technology or as an example of said debasement of reason. In this context, he says the following about the genocide (in the lecture that was later revised into "The Question concerning Technology"): "Agriculture is now a mechanized food industry, in essence the same as the manufacture of corpses in the gas chamber and extermination camps, the same as the blockade and starvation of the countryside, the same as the production of the hydrogen bombs" (quoted in Lang, 1996: 16).

Heidegger addressed the issues of fascism and genocide and did so by way of a critique of instrumental rationality. Before the rise of Nazism, the political crisis of the Weimar era was but a symptom of a deeper spiritual crisis brought about by Enlightenment rationality. During the Nazi era, the revolution was the proper way to respond to the deeper spiritual crisis brought about by Enlightenment rationality. After the war, the Nazi era came to be a symptom of, rather than a solution to, the spiritual crisis brought about by Enlightenment rationality. Even the genocide itself is but a symptom of this deeper crisis. Of the three thinkers we are examining in this paper, it is Heidegger who is the most ripe for criticism. This is in large part because the best that one can say is that his political judgments are disastrously erroneous rather than, as many critics charge, actively malicious. Philosophically, his argument functions at a level of abstraction that is deeply disturbing and is at odds with the hermeneutical concern to avoid abstraction and focus on factical existence. When he is not employing philosophical terms to defend the Nazi revolution he is employing essentialized thinking that leads him to avert his gaze from genocide in its specificity. By reducing the Holocaust to a symptom of a deeper problem, Heidegger implies that the messy details of the Holocaust are less significant than the essence of technology. This level of abstraction ensures that Heideggerian hermeneutics is unable to think the Holocaust.

\section{Gadamer}

If Heidegger was an enthusiastic Nazi, the same cannot be said for his student H.G. Gadamer, who was too benign a figure to be seduced by his mentor's foolishness. Gadamer, who worked with Heidegger before the master moved to Freiberg, was as shocked by his teacher's revolutionary enthusiasm as Heidegger was disappointed by his student's refusal to seize the moment (see Grondin, 2003: 154-156, 187-189). Once the Nazis seized power, Gadamer's temperament led him to keep a low profile and to make whatever accommodations with the current situation as were necessary to maintain his career while refraining from becoming complicit in the horrors around him. Unlike his fellow hermeneuts, who explicitly wove their reflections on both fascism and genocide into their thought, Gadamer chose the path of silence. The universities had been thoroughly politicized in the Nazi era, with approximately half of the professional philosophers joining the party (Sluga, 1993: 7) and major figures straining to show that their particular school of philosophy provided the best ground for the Nazi revolution (see Sluga, 1993: 81-100, 125-153; Faye, 2009: 151-202, 224-237). In the wake of this, a number of post-war intellectuals untainted by Nazism publicly called for a decade(s)-long period when the universities were either closed or ruled by the occupying powers (Grondin, 2003: 241), fearing that the same forces that produced Nazism would prove to be incapable of resisting the lure of authoritarianism and fascism. Gadamer, who was both in Germany and untainted by explicit collaboration, was well positioned to emerge as a post-war academic leader who was free from the stain of collusion.

Gadamer gave a number of speeches in which he laid out his vision of German cultural and intellectual life that could emerge from the ashes of moral collapse and total military defeat. According to Grondin (2003: 243-252), a number of key themes emerge from his vision of a revived German intellectual world. In these lectures he sought to rehabilitate the tainted tradition and to challenge those intellectual tendencies that had sullied the tradition in the first place: the instrumentalization and politicization of thought, which encouraged intellectuals to discard the quest for truth and to serve a corrupt political regime; and the tendency for Romantic longing, which had left intellectuals and German culture open to the lure of racial mystification. In particular, he identified Romantic longing as paving the way for the catastrophe. "This seems to me one of the most decisive tasks that scholarship can perform for the whole: educating the Germans to reality. Romantic longing must be driven out of our youth and our people once and for all" (quoted in Grondin, 2003: 246). As he sought to drive out Romantic nationalism from the discourse, he also gave a number of lectures on what he saw as the best of the German tradition. The challenge would be to find a way to revive that tradition without discarding the literary in the name of Enlightenment rationality but without also indulging in dangerous Romanticization. This task would form the horizon out of which would emerge his magnum opus: Truth and Method. The foundational text of the discipline of hermeneutics was written as a response to fascism and genocide with the discipline emerging as the best way to avoid relapsing into the horror.

Gadamer's explanation for this sorry state of affairs should be rather familiar by now. The problem that forms the backbone of Truth and Method is Enlightenment rationality, which is itself rooted in flaws in the metaphysical tradition that goes back to the Greeks. In his reading, these flaws can be traced back to a misreading of Aristotle, a misreading corrected by the young Heidegger before his foolish Nazi turn. The solution comes with an authentic confrontation with the great works of the Western tradition, a confrontation tainted by neither objectification nor politicization. This confrontation can only take place after we have discarded the flawed interpretive stance that is rooted in instrumental rationality.

Because of the Enlightenment, rationality has been reduced to science and mathematics and art and the human sciences have been reduced to silence or misconceived. This is central to Gadamer's analysis. According to Gadamer, scientific rationality 
and its heirs produce thought that is fragmented and "strangely detached" (xv), “ossified" (375), estranged (149), alienated and alienating (280) and "depends on a process of abstraction" (76). This abstraction produces "epistemological dogmatism" and "dogmatic abstractions" (81-82). "It is the aim of science to so objectify experience that it no longer contains any historical element" (311). The volume opens and closes with his rejection of scientific reasoning. In the Introduction he asks what kind of truth and insight can come from art and then says, "In the face of the dominant position of modern science in the philosophical clarification and justification of the concept of knowledge and the concept of truth, this question does not appear legitimate" (xi). The final paragraph of the book concludes that "the certainty that is imparted by the use of scientific methods does not suffice to guarantee truth" (446) because "what the tools of method does not achieve must ... be achieved by a discipline of questioning and research, a discipline that guarantees truth" (447). It also finds its way into the title, where truth in the form of art and the Western tradition is placed alongside and ultimately in opposition to the enlightened, scientific rationality of method. Drenched in instrumental reasoning, method is alien to the human sciences and should not have become the yardstick for thinking about art and the intellectual tradition and heritage. The impoverished methodological tradition can be traced back to Kant and the Enlightenment. Kant's thought "constituted a turning point" in the doomed desire to model the human sciences on the natural sciences (38). "The importance of this cannot be easily overestimated, for what was here surrendered was that element in which literary and historical studies lived" (38). As a result of this turn to Enlightenment, "the human sciences lost its justification" (38-39). Gadamer's argument goes something like this: the Enlightenment led to the triumph of the scientific method as the sole and legitimate form of human knowledge. This limiting of human knowledge to scientific methodology led to the "selfannihilation" of the human sciences (19).

The Romantic rebellion against Enlightenment's scientism seems to offer a way out, but Gadamer demurs. He argues that it remains excessively rooted in Kant and Enlightenment thinking. "Romantic hermeneutics and history found a point of contact for their self-understanding only in the concept of genius stressed by Kant's aesthetics" (39). As a result, "the romantic critique of the Enlightenment ends up in Enlightenment" (244). By rooting itself in the inward experience of the autonomous individual, romanticism aesthetics and historiography produces the subjectivisation of the aesthetic experience (39-73), thereby closing off the possibility of artistic truth (73-90). The Enlightenment brings with it a form of subjectivism that carries "destructive consequence(s)" (85), as does the Romantic rebellion against Enlightenment.

The scientific method produces a stance of distanciation: isolated subjects dissecting moribund objects rather than factical Dasein encountering a living world. It presumes and leads to intellectual and ultimately social alienation, atomism and rootlessness. There is a direct line from the elevation of science, the distancing effect inherent in the scientific method, a subjectivist rebellion, and the alienation and historical confusion that result (see 211-214). The solution, then, to the problem of social alienation and its negative social effects can be found in providing the human sciences with a theoretical foundation that is essential to its nature. The problem is Enlightenment and its major tool of instrumental rationality and the solution is philosophical hermeneutics. It is hermeneutics that can free modernity from the philosophical errors and from the horrifying cultural/political events that grow out of these errors. Meditating on the phenomenological structure of interpretation may not seem like a proper response to the horrors of the Nazi era and the genocide, but, according to Gadamer, without such philosophical reflection we are bound to repeat the horrors anew.

The challenge is to develop a view of art and its interpretation that manages to avoid the twin pitfalls of positivistic objectivism and romantic subjectivism, and the solution is to be found in a Heideggerian phenomenology (225-234). His goal is to "enquire into the mode of being" of the experience of art, an experience that does not leave the subject unchanged (89). He also argues that this analysis has implications well beyond the realm of art, giving hermeneutical theory a comprehensive breadth well beyond the aesthetic realm (146). This framework forms the foundation for most of his major theoretical achievements: the hermeneutical circle, the fusion of horizons, the avoidance of the aesthetic consciousness, the rehabilitation of prejudice and tradition. These seminal ideas, all central tenets of the discipline of hermeneutics, emerge out of Gadamer's reaction to the Nazi era as defined by instrumental rationality and romanticized enthusiasm. The hermeneutical circle (235-237) avoids the pitfalls of objectification. The dialogue implicit in the hermeneutical circle provides interpretation and textual encounter with its ontological-hermeneutical structure that is preferable to the detached observer dissecting dead objects. The rehabilitation of prejudice, which gives presuppositions a productive role in the creation of knowledge, avoids the Enlightenment's embrace of objectivity and affirms the historical nature of human existence. The hermeneutical circle allows him to go beyond romantic aesthetics and the aesthetic consciousness. The aesthetic consciousness is as much an abstraction as the distancing that comes with the scientific method $(72,76)$, and produces alienation every bit as severe as the alienation produced by the scientific method (75). He rejects the historiographical goal of the objective reconstruction of the past (336-338) that participates in Enlightenment, objectivist errors. Instead he argues for the fusion of horizons, which he sees as providing an ontological, hermeneutical ground for historical inquiry.

In what is most relevant to our discussion, Gadamer is eager to redeem the seemingly tainted notion of tradition. In the immediate postwar era he was eager to redeem tradition from its association with racism and Nazism. While the connection to Nazism is no longer in the foreground, his concern with redeeming tradition remains strong in Truth and Method and, once again, it is done by way of a critique of instrumental reason. In the wake of the Enlightenment, tradition has been seen as antithetical to (instrumental) reason and aligned with the negative force of prejudice (240). The romantic revolt is no more satisfactory in that it accepts the reason/tradition divide and elevates the formerly scorned half of the dichotomy (250). Rather than being a static object to be dissected, it is constantly created and recreated in the course of the encounter. Despite the distortions of dictatorial regimes (n. 187, page 524), tradition possesses authority only to the extent that it possesses wisdom and that its wisdom is properly encountered and accepted.

In each instance, Gadamer's thought seeks to identify how the Enlightenment has left us intellectually impoverished and even opened the door to a whole range of horrors, from alienation to dictatorship. He has tried to work through the various dichotomies and replace them with a philosophically sound historical hermeneutics. Unlike his mentor, Gadamer made every effort to stay clear of political entanglement, but it is not clear that the crisis produced by the Nazi era stayed clear of him. In particular, his rehabilitation of both prejudice and of notions of National Tradition reveals blind spots to his approach. It is not so much that he is implicated in the racism of the Nazism by rehabilitating the notion of prejudice in the hermeneutical process. It is rather that, after the searing experience of Nazism and of other forms of modern racial prejudice, it seems woefully 
inadequate to say that all that is required is an open mind and a willingness to enter the hermeneutical circle. There is more wrong with prejudice than a closed hermeneutical stance, and hermeneutics lacks the means for a full and thoughtful confrontation with the wide range of prejudice and the damage that it can bring. The same flaw is found in Gadamer's reflections upon notions of the tradition. His hermeneutical reflections here are not without insight, and he is careful to separate authentic tradition (as an ongoing dialogue) from the sort of crass cultural nationalism that supported Nazism. But, once again, he is not terribly helpful in providing a way to identify where a tradition goes off the rails and how to confront it; nor is he particularly clear on the more problematic link he draws between a cultural tradition and an ethnic group. He is in danger of embracing a more elevated form of cultural nationalism. At the very least, his thought does little to help us escape from such a fate.

Furthermore, despite the many differences between himself and Heidegger, his thought is open to many of the same criticisms that have been articulated above. While his hermeneutical theory is hardly reducible to a displaced response to Nazism, there exists a profound connection between his intellectual and aesthetic project and the atrocities carried out in the name of the German tradition that he so admires. His hermeneutical theory - with its emphasis on overcoming the dichotomies bequeathed by the Enlightenment and its attempt at overcoming alienation and atomism - represents his confrontation with the crisis of modernity, which includes Nazism and its after effect. Unlike Heidegger, he is not directly addressing the genocide, but he is clearly envisioning an alternative approach to history, art, culture and the Western tradition, an alternative that would help us avoid another brush with fascism and genocide. The problem here, as with Heidegger, is that by focusing so heavily on the roots and origins and essences, he encourages us to look away from genocide and fascism in their specificity.

\section{The Frankfurt School}

The members of the Frankfurt School did not have the opportunity to become Nazi enthusiasts, nor did they have the option of quietly riding out the war free from dangerous or disreputable political entanglement. The mostly Jewish and entirely socialist scholars who made up the Frankfurt School were not destined to last long in Hitler's racial utopia. Upon Hitler's rise to power various members of the school went into hiding, eventually setting up a semi-permanent exile in New York City, loosely aligned with Columbia University. Of all of the theorists we are looking at, their philosophy was the most explicitly and thoroughly political. From their perch in the United States, they waged a relentless intellectual war against the foundations of Nazism, producing major studies on prejudice and anti-Semitism, the Authoritarian Personality, and Nazi political and legal theories. They also wrote major philosophical works that overlap to a significant degree with our topic and deserve careful attention. One might be tempted to observe that the hermeneutical flaws identified above are limited to the phenomenologists - to Heidegger and his student Gadamer. The hermeneutical position of the Frankfurt School suggests otherwise.

In particular they see fascism as reflecting a deeper crisis of modernity, primarily because of the ubiquity of instrumental rationality - a crisis that is ultimately rooted in antiquity. It is Adorno who quips that Heidegger's thought is fascist down to its core, yet the structure of their critique bears striking resemblance to that of the phenomenologists. Like Heidegger and Gadamer before them, members of the Frankfurt School were profoundly shaped by Nazism and developed a critique whereby the current phenomenon of fascism is but a symptom of a deeper philosophical error. The two most influential founders of the Frankfurt School, Horkheimer and Adorno, do develop a philosophical argument that is strikingly phenomenological.

For Horkheimer and Adorno, Jewish-German exiles and authors of the brilliantly infuriating Dialectics of Enlightenment, the best way to confront the horrors of fascism and genocide is by rethinking the Enlightenment, broadly defined, and by tracing the roots of the Enlightenment's failings back to the ancient Greeks. This theory may seem counterintuitive, given their radical socialism, their embrace of empiricism, their critical analysis of popular culture, their exile from Germany, and their contempt for Heidegger. Adorno penned an acerbic assault on Heideggerian existentialism, accusing Heidegger of using philosophy to universalize capitalism, fascism and maudlin folksy nationalism (Adorno, 1973: 19-20, 25, 55-60, 71, 76, 92-120). Despite these differences, Horkheimer and Adorno do embrace a philosophical narrative as a way of explaining fascism and genocide that is remarkably similar to that of Heidegger and Gadamer. They all produce a common narrative in which the Enlightenment, as the fulfilment of all that is wrong with Western thought, is the ultimate source of the genocide.

For Horkheimer and Adorno, fascism is an enemy that must be confronted and defeated. To defeat fascism requires seeing it as part of modernity and, therefore, as grounded in the dialectics of Enlightenment. The goal of thought must be to find forms of rationality that are precluded by the Enlightenment reduction of reason to technical rationality. Once again this involves tracing this reduction back to its roots in Greek antiquity, the ultimate source of what inspires and dooms modernity. Horkheimer and Adorno differ from the phenomenologists by tracing the originary Greek moment back to myth rather than philosophy.

Rather than being a source of liberation, the Enlightenment's promise to liberate humanity from myth, from fantasy and from fear (Horkheimer and Adorno, 2002: 1) includes within it a dark side in that it also installs humanity as master over nature and over each other (ibid). The result is a "wholly enlightened earth" that is "radiant with triumphant calamity" (ibid). The scientific mind conquers superstition and in the process "rules over disenchanted nature" (2). Enlightenment thought never learned the joy of understanding but only "the method of exploitation" of nature and of others (ibid). The violence at the heart of the Enlightenment assault on myth leads to an entire range of violent thought and actions, rejecting anything "that does not conform to the standard of calculation and utility" (3). "Enlightenment is totalitarian" (4) because it has granted unlimited power to calculating thought (678), multiplying violence upon violence (33). In the process it reified thought, "aping the machine it has produced itself" (19). Nazism, which pays tribute to the Enlightenment as it claims to free itself from it (37), is but one form taken by modern totalitarianism (43). Like Heidegger before them, Horkheimer and Adorno see a direct line from Enlightenment principles to instrumental reason to social and political catastrophe.

For Heidegger and Gadamer, the Enlightenment itself grows out of flaws in the Western tradition than can be traced back to the ancient Greeks. Horkheimer and Adorno state something remarkably similar, arguing that the Enlightenment's mode of thought may be thoroughly modern but that it has its roots in the origins of Western thought. If Heidegger and Gadamer locate the problem in unfortunate features of formative philosophy, Horkheimer and Adorno locate it in the realm of myth and its reception. This is partly because they identify philosophy, since its inception in Plato and Aristotle, with claims to universality and therefore to domination (16). But it is also because they locate within mythology the power to both enslave and liberate. If the historical Enlightenment is totalitarian, it is within mythology, or 
at least within Homer's articulation of mythology, that one finds the dialectic of Enlightenment. For the process of objectification is already "far advanced in the Homeric epic" (11) and "the Odyssey as a whole bears witness to the dialectical of Enlightenment" (34). It is Homer who sets in motion the process that culminates in the totalitarianism of modern science and, eventually, genocide.

There are also, in Homer, the seeds for rebellion against Enlightenment's totalitarian nature. The dialectic remains, since Odysseus "achieves his estrangement from nature by abandoning himself to nature" (38). In Homer there exists unity through multiplicity rather than simply the triumph of the universal over the particular (as in later, undialectical Enlightenment). The Enlightenment, however, is based on the fear of the mythical and the ensuing desire to expel the mythical from the realm of reason. The dialectic is destroyed in the quest for monolithic unity as the Gods and the primal, including nature, are to be violently excluded. The Enlightenment exists in a state of terror in the face of the mythic (22), with the mythic here being conceived quite broadly. It is ambiguity itself that is the ultimate target of the Enlightenment. Fascism is ultimately rooted in the fear of ambiguity and that fear has taken hold because Western Philosophy is structured around eliminating ambiguity. Fascism is but one symptom of this ancient desire.

Fascism is the enemy and the authors are withering in their critique. Yet fascism remains a particularly archaic surface reflection of deeper powers that can be traced back to the Enlightenment impulse $(18,22,30,33,37)$. These same forces create other forms of totalitarianism, including ruthless capitalism (43) and American popular culture, which withers the imagination (100). Fascism is distinguished from other totalitarianisms by its extremism and by its vacuity (172). It also includes two other distinctive factors, antiSemitism and genocide, both of which are rooted in the Enlightenment itself. Understandably, the topic of anti-Semitism receives considerably more attention from Horkheimer and Adorno (2002: 137-172) than from either Gadamer (where it is never broached) or Heidegger (where one can find disturbing traces of anti-Semitism). In their complex argument, the image of the Jew is constructed to serve a number of purposes: to embody all that the fascist regime fears (165) and to embody the economic exploiter and thereby distract the populace from capitalism's structural exploitation (143). Like all else in the modern world that does not fit into the current order, they must be rooted out (150). "As they designate obsolete sections of the population for extermination the administrations of totalitarian states are merely the executors of economic verdicts passed long ago" (171). Long ago in this instance refers to the Enlightenment because, ultimately, even the genocide is an outgrowth of logic of Enlightenment. With the genocide, the Enlightenment itself finally sought to "break through the limits of Enlightenment" (172).

The Frankfurt School was particularly well positioned to avoid the errors identified with the phenomenological branch of hermeneutics. Their political commitments and empirical work suggest that they are looking at rather than away from fascism and genocide, while their empirical work suggests an approach capable of avoiding the trap of essentialism. It is all the more revealing that they too end up repeating the same hermeneutical narrative that locates the essence of fascism and genocide in instrumental rationality and flaws located in the origins of the Western tradition. For all their sophistication, they are unable to escape the lure of this powerful narrative.

\section{Conclusion}

This paper presents a challenge to mainstream approaches to hermeneutics, especially as appropriated by biblical scholarship. Current hermeneutical theory has been quite attentive to specific philosophical questions about the fundamental nature of rationality, meaning and interpretation. While these are important questions that require continued attention, the implication is that socio-political questions are extraneous to ontological analysis. I have demonstrated that issues ranging from alienation to fascism and genocide were anything but peripheral to the work of the discipline's foundational figures. Current hermeneutical theory should be as attentive to these sorts of questions as were the foundational figures of the discipline. Mainstream hermeneutical theory, especially as envisioned by biblical scholars, needs to open itself up to a much broader range of questions, issues and perspectives.

Furthermore, the paper has identified problems with the specific nature of the hermeneutical approach to matters of interpretation and to fascism and genocide. The three thinkers/ schools of thought identified above possess substantial differences in everything from their fundamental philosophical-aesthetic outlook to their political commitments. They share remarkably similar views about the ills of modernity (that is, alienation, rootlessness) and a remarkably similar narrative on how these ills came about. In this grand narrative, current political or social problems are surface symptoms of a deeper spiritual crisis. This spiritual crisis is caused by philosophical errors that go back to the very roots of Western philosophy or literature. Finally, for all three the Enlightenment represents a fateful step in the decline of Western history when instrumental reason triumphed over all else. The philosophical and the political side of the hermeneutical project are deeply intertwined, which is why hermeneutical theory can claim to identify the conditions that make textual interpretation possible and, in the same step, free us from the ill effects of modernity. The proper nature of meaning and interpretation can only be discerned if Enlightenment-induced errors are identified and circumvented. The same is true of fascism and genocide.

Because this philosophical narrative is woven into both philosophical and political questions, I would like to conclude by summarizing some of the limitations that have been identified through the course of my analysis.

(i) This paper has identified a number of problematic philosophical issues. There is an unexamined teleological assumption at work where ancient errors inevitably lead to a modern nightmare. There is a related problematic view of causality in which philosophical errors inevitably produce social crisis while proper philosophical categories alone can produce a healthy society. Finally, the view of the Enlightenment is entirely one-sided and reductive. The oft-repeated return to the Enlightenment as an explanation for virtually all that has gone wrong with modernity suggests unexamined animosity rather than thoughtful engagement. Certainly there is more to the complex historical phenomenon of Enlightenment than instrumental reason and its ill effects.

This is not to suggest that the hermeneutical argument is not without value. It is worth identifying Enlightenment's dark side, and, with a more nuanced and dialectical approach, hermeneutics could initiate a productive conversation about the contradictory effects of Enlightenment. In the same way, there is much to praise in the critique of instrumental reason. Were the hermeneutical position framed in less teleological and more empirical terms, the critique of instrumental reason could be quite fruitful. The challenge is to disentangle the central categories of hermeneutics - from the hermeneutical circle to the productive role of presuppositions - without overstating the pernicious effects of instrumental reason.

(ii) The hermeneutical approach to genocide and fascism is equally problematic. Central to my argument is the claim that the critique of instrumental reason is offered as a way of confronting 
(or, in Heidegger's case, defending) fascism. The analysis above raises a number of questions about this as a way to confront fascism and genocide. It is ultimately reductive to see genocide as a mere reflection of a deeper spiritual problem. It is further concerning that this position is unable to be attentive to fascism and genocide in their specificity and is unable to explain why individual genocides occur where and when they do. The hermeneutical position is that instrumental reason produces abstraction, alienation, ambiguity-hating universalism, atomization, isolation, technological supremacy, domination of nature, and blindness to the truth of art and that fascism and genocide somehow emerge out of this mixture. Within this way of thinking there is no need to explain in detail the connections between the various links in the chain. In the language of hermeneutics, this approach reduces genocide to an abstraction rather than identifying its facticity. It diverts our attention away from the Holocaust itself without creating a dialogue with the Holocaust's reality. It is a hermeneutical approach that, on this point, eschews the "to and fro" of the hermeneutical circle.

Once again, this is not to suggest that the hermeneutical approach has nothing to offer Genocide Studies. Rather than being an irrational irruption of atavistic rage, genocide is often rigorously rational, and hermeneutics could play an extremely helpful role in teasing out the forms of rationality being employed. It could also connect genocidal rationalities to other modern modes of rationality. This would be a very different sort of analysis, more attuned to how genocidal modes of rationality function than to genocide's roots in antiquity. There is little of this sort of analysis in current comparative Genocide Studies, and hermeneutical theory would be particularly well situated to fill this scholarly gap.

There is a further problem as well. The hermeneutical approach limits its attention to one aspect of genocide (that is, its form of reasoning) while rendering invisible everything else that makes genocide possible - from political structures to the role of law to the relationship between racism/imperialism and genocide. I suggest that New Testament scholars, including those of us indebted to the hermeneutical project, look more directly at the scholarly fields of Holocaust and comparative Genocide Studies. These disciplines can provide an entire range of questions and issues that will end up enriching both hermeneutics and the discipline of Biblical Scholarship.

\section{References}

Adorno A (1973) The Jargon of Authenticity; trans. K. Tarnowski and F. Will. Northwestern University Press: Evanston.

Bambach C (2003) Heidegger's Roots: Nietzsche, National Socialism, and the Greeks. Cornell University Press: Ithaca.
Farias V (1989) Heidegger and Nazism; ed. and trans. J. Margolis and T. Rockmore. Temple University Press: Philadelphia.

Faye E (2009) Heidegger: The Introduction of Nazism into Philosophy; trans. M. B. Smith. Yale University Press: New Haven.

Gadamer H G (1988) Truth and Method; trans. revised by J. Weinsheimer and D. G. Marshall. Crossroads: New York.

Grondin J (2003) Hans-Georg Gadamer: A Biography; trans. J. Weinsheimer. Yale University Press: New Haven.

Heidegger M (1993a) The self-assertion of the German university trans. W. Lewis. In: Wolin R (ed) The Heidegger Controversy. MIT Press: Cambridge, pp 29-39.

Heidegger M (1993b) 'Only a god can save us', Der Spiegel's Interview with Martin Heidegger trans. M. Alter and J. CaputoIn: Wolin R (ed) The Heidegger Controversy. MIT Press: Cambridge, pp. 92-116.

Horkheimer M and Adorno T (2002) Dialectic of Enlightenment: Philosophical Fragments; trans. G. S. Noerr. Stanford University Press: Stanford.

Kisiel T (1995) The Genesis of Heidegger's Being \& Time. University of California Press: Berkeley.

Kelley S (2002) Racializing Jesus: Race, Ideology and the Formation of Modern Biblical Scholarship. Routledge: London.

Lang B (1996) Heidegger's Silence. Cornell University Press: Ithaca.

Ott H (1993) Martin Heidegger: A Political Life; trans. A. Blunden. Basic Books: New York.

Phillips J (2005) Heidegger's Volk: Between National Socialism and Poetry. Stanford University Press: Stanford.

Porter S and Robinson J C (2011) Hermeneutics: An Introduction to Interpretive Theory. William B. Eerdmans Publishing: Grand Rapids.

Porter S and Stovel B (ed) (2012) Biblical Hermeneutics: Five Views. InterVarsity Press: Downers Grove, IL.

Safranski R (1998) Martin Heidegger: Between Good and Evil; trans. E. Osers. Harvard University Press: Cambridge.

Sluga H (1993) Heidegger's Crisis: Philosophy and Politics in Nazi Germany. Harvard University Press: Cambridge.

Van Buren J (1994) The Young Heidegger: Rumor of the Hidden King. Indiana University Press: Bloomington.

Wolin R (ed) (1993) The Heidegger Controversy. MIT Press: Cambridge.

\section{Data availability}

Data sharing not applicable to this paper as no datasets were generated or analysed during the current study.

\section{Additional information}

Competing interests: The author declares no competing financial interests.

Reprints and permission information is available at http://www.palgrave-journals.com/ pal/authors/rights_and_permissions.html

How to cite this article: Kelley S (2015) Hermeneutics and genocide: giving voice to the unspoken. Palgrave Communications. 1:15031 doi: 10.1057/palcomms.2015.31.

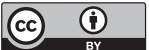

This work is licensed under a Creative Commons Attribution 3.0 International License. The images or other third party material in this article are included in the article's Creative Commons license, unless indicated otherwise in the credit line; if the material is not included under the Creative Commons license, users will need to obtain permission from the license holder to reproduce the material. To view a copy of this license, visit http://creativecommons.org/licenses/by/3.0/ 